\title{
PIERO GOBETTI'S AGONISTIC LIBERALISM
}

\section{ABSTRACT}

This essay examines the "revolutionary liberal" outlook expounded by the young Italian journalist and intellectual, Piero Gobetti, immediately following the First World War. It considers the historical evolution of his "agonistic" liberalism according to which conflict rather than consensus serves as the basis of social and political renewal. The essay traces the formation of Gobetti's thought from his idealist response to the crisis of the liberal state, through to his endorsement of the communist revolutionaries in Turin and his denunciation of fascism as the continuation of Italy's failed tradition of compromise. Whilst Gobetti's views presently resonate with a growing interest in the agonistic dimension of politics, it is argued that his elitism and his understanding of liberalism as a "civic religion" reveal challenging tensions in his thought.

James Martin

Department of Politics

Goldsmiths College

University of London

New Cross

London SE14 6W

Email.j.martin@gold.ac.uk 
Can liberals deal with conflict? Of course they can, it is argued: moral disagreement has always been integral to the liberal ethos. The price paid for subduing "heretical opinions" proclaimed JS Mill "is the sacrifice of the entire moral courage of the human mind". ${ }^{1}$ Yet, disagreement has often been narrowed down by liberals to disputes within a framework of previously agreed norms and institutions. Outside of any prevailing "normative consensus," however, where certain epistemological assumptions or cultural values do not prevail, conflicts between "incommensurable" ideals and beliefs threaten to unravel into a more dangerous situation of enmity and violence. Thus are contemporary political philosophers increasingly drawn to the idea of conflict as a constitutive dimension of political order. ${ }^{2}$ Rejecting a universal rationality, yet steering clear of any unreflective appeal to "tradition," some now underline the intrinsically agonistic dimension of politics. That is, they claim political communities are formed not on the basis of the common denominator of Reason that might enable disagreement to be contained within some overarching consensus, but that "conflict, both within liberal forms of life and between these and other forms of life" is an "ineliminable and therefore permanent feature of the human condition." 3

This essay discusses the agonistic liberalism of a relatively unknown Italian political thinker and journalist, Piero Gobetti (1901-1926). Although he died tragically young, at the age of twenty-five following a beating by Mussolini's fascists, Gobetti's own brand of "revolutionary liberalism" renounced metaphysical foundations and acknowledged conflict as the basis to political life. Arguing in a context where a normative consensus of liberal values was clearly absent, Gobetti stands out as an early defender of a progressive liberal realism. As such, his thought bears comparison with other European thinkers of the interwar period, such as Carl Schmitt, who were similarly inspired to uphold the centrality of politics by substituting liberal consensus with a conflict-based outlook. Unlike other thinkers, however, Gobetti aimed to make liberalism itself a theory of conflict in order to revive its prospects in the face of fascist reaction. ${ }^{4}$ 
Gobetti's heretical liberalism, as we shall see, expanded upon an idealist opposition to abstract rationalism and transcendental systems. For him, liberalism did not imply a fixed, atomistic notion of human nature. Instead, the term "liberal" invoked an ethic of struggle against transcendental beliefs, an effort at liberation from imposed, hierarchical systems. Thus he was able to associate liberalism with revolutionary movements such as Russia's Bolsheviks and, in Turin, the factory council movement led by the communist Antonio Gramsci. After reviewing these associations, as well as his novel critique of fascism, I will evaluate the connection he made between liberty and struggle. I argue Gobetti's thought presents an important lesson to contemporary liberals concerning the polemical basis of their values, but it also exemplifies the difficulties liberals might have in taking on this lesson.

\section{THE CRISIS OF "LIBERAL ITALY”}

Gobetti, as one commentator has put it, was the "boy-wonder of Turin" in the tumultuous years following the end of the First World War. ${ }^{5}$ The tremendous impact of this precocious young man, gathering around him a wealth of intellectual talents and initiating the early antifascist movement, is owed in part to the dramatic context in which he lived and worked. Gobetti matured rapidly and worked frenetically as a political commentator in the war's immediate aftermath as Italy plunged into social and political crisis; a situation that led, eventually, to Mussolini's "seizure" of power and the end of parliamentary democracy. Thus, as I will demonstrate below, Gobetti's thought-and particularly his agonistic reformulation of liberalism—is directly bound up with this crisis and decline of "liberal Italy."

Throughout his career as a public intellectual-a tragically short seven years-Gobetti was motivated by a profound sense of the need for cultural and political renewal in Italy. Such aspirations were then widespread throughout the peninsula. The urge for renewal resonated with a deeper and longer-held sense, particularly amongst intellectuals, of the need for a "civic religion" in Italy, that is, a common, secular morality that would unite the fragmented nation with its polity. ${ }^{6}$ The First World War, however, was the final nail in the coffin for the liberal regime: at home, military discipline and economic deprivations for working people 
generated deep resentments; when combined with the military injuries and loss of life, disappointment at the meager territorial gains and economic recession, the calls for renewal began to proliferate. ${ }^{7}$

Gobetti's journalism began in 1918 when, at the age of seventeen, he and some friends set up their own review, Energie Nove ("New Energies"). An exceptionally gifted and intellectually mature child, Gobetti had joined the University of Turin in the same year that Europe's Great War ended. Turin's university was known for the strong sense of intellectual leadership and civic responsibility of its members, particularly the Faculty of Law into which Gobetti entered. ${ }^{8}$ Energie Nove followed a similar vein of post-war publications calling for radical cultural renewal and asserting the need to reconnect political and ethical life in a new, morally inspiring outlook. For many Italians, the war's end signaled the exhaustion of parliamentary politics. Long despised for its elitism, corruption and failure to win the support of the vast majority of the country, liberal politics now seemed utterly anachronistic. Despite government concessions such as electoral reform, the dopoguerra (post-war period) was characterized by a pervasive atmosphere of anti-parliamentarism and an intense expectation of change. ${ }^{9}$ Intellectuals and other public figures from across the political spectrum clamored to define and lead this expectation, dismissing party politics as ineffectual and calling for a deeper, "spiritual" transformation of public life that would invest it with greater inclusivity and vitality.

The dominant strain in this ferment of intellectual radicalism was idealism and like many other thinkers of his generation Gobetti's early work owed much to its leading proponent, Benedetto Croce, a figure of singular influence in Turin. ${ }^{10}$ At the turn of the century Croce had inspired a generation of intellectuals to renounce positivism and conceive society and history as the product of creative subjectivity. In his "immanentist" philosophy, which opposed itself to all transcendental, metaphysical claims, human progress stemmed not from abstract knowledge of objective laws but from an affirmation of the role of "spirit" in practically confronting and shaping the world. Only through a serious and committed grounding of 
ourselves and our lives in the historical problems we confront individually, he argued, could we find meaning and value in our existence. ${ }^{11}$ This austere "facing-up" to the world we inherit and make by ourselves without any metaphysical guarantee, Croce thought, could itself serve as Italy's long-desired secular faith. Though not a professional academic, Croce's lesson nevertheless inspired the aesthetic radicalism of journals such as Giovanni Papini's La Voce and Giuseppe Prezzolini's Leonardo which, rather to the Neapolitan's concern, had extended his historicism and subjectivism into a wholesale revolt against rationalism. ${ }^{12}$

Gobetti identified Energie Nove explicitly with Croce, Papini and Prezzolini. ${ }^{13}$ In a key article of May 1919, "La Nostra Fede," he presented the project of the review precisely in terms of the formation of a new faith. Denouncing the parliamentary parties for their "vast and imprecise formulae," for representing egoistic and not common interests, successful only in ensuring the "triumph of personal interests with the complete absence of ideals," Gobetti diagnosed the "misadventures of Italian public life" in "the absence of sincerity and clarity," a condition expressed perfectly in giolittismo (the parliamentary maneuverings of Giovanni Giolitti, Italy's frequent, yet much maligned, liberal prime minister). ${ }^{14}$ Political values, he claimed, were out of step with the needs of everyday life. The remedy to this unhappy condition, he declared, was "a healthy rethinking of ideas."

Rejecting party doctrine in favor of a new spiritual disposition was not, however, an easy option. For it required not merely the renunciation of the parties' "mental schemes" but "an entire moral upheaval."16 At the basis of this idealist revision of thought and action was a distinctly Crocean message, the absolute immanence and dynamic, self-creating force of human spirit. ${ }^{17}$ For Gobetti, idealism set itself against all "revealed truths," especially those of the parties, and substitutes for them "the truth that is conquered day by day with the work of each." ${ }^{18}$ That meant arousing a "profound passion" that challenged apathy and indifference: "Honesty consists in having ideas, and believing them and making them the center and purpose of oneself. Apathy is the negation of humanity, abasement of oneself, absence of 
ideality." ${ }^{19}$ Absorbing this rather pious message, for Gobetti, was not simply a matter of private personal salvation. It was, he insisted, the only way politics could be done.

Gobetti's liberal orientation pushed him at this time towards a radical political reformism. Like many young intellectuals, he was attracted to the battles of the independent socialist and long-standing critic of the liberal regime, Gaetano Salvemini. ${ }^{20}$ Although aimed at a range of literary and cultural topics, Energie Nove helped publicize Salvemini's campaigns against the parliamentary "transformism" and political neglect of the "Southern Problem" and his journal devoted issues to shared concerns such as school reform ${ }^{21}$ and the international situation. Naturally, like Salvemini, it was deeply critical of the liberal political elite. ${ }^{22}$

However, by the end of the 1919 the political situation in Italy had begun to shift significantly. In September the poet Gabriele D'Annunzio led an expedition of a thousand troops to "seize" the north-eastern border town of Fiume, so giving form to a widespread sense of dissatisfaction with territorial gains after the war and heightening the sense of an unresolved national crisis. ${ }^{23}$ In November, general elections were held on a new system of proportional representation. The results saw a large increase in votes and parliamentary deputies for the Socialist Party, as well as the new, Catholic, Popular Party (results later confirmed in the local elections in Autumn 1920). ${ }^{24}$ Increasingly, Italian middle classes became fearful of an evident shift to the left. The socialists gains, argued Gobetti, portended Italy's ruin. ${ }^{25}$

Throughout December 1919, Gobetti seemed prepared to continue his editorship of Energie Nove and had even sketched out several plans for its development into a larger and more thematically comprehensive journal. ${ }^{26}$ However, in February 1920 he interrupted these plans, calling for an intermezzo in the review's publication which, in fact, was never recommenced. ${ }^{27}$ Gobetti declared his desire to rethink his activities; elsewhere vowing to continue supporting Salvemini and other cultural activities in Turin. ${ }^{28}$ But in a private letter he suggested he had undergone an "intimate crisis." ${ }^{29}$ The reformist politics he had been pursuing, he later admitted, seemed overly fragmented and lacking in intellectual vision. ${ }^{30}$ Over the course of the next two years, Gobetti's intellectual and political focus shifted 
dramatically as Italy's crisis deepened and revolutionary upsurges spread throughout the industrial North and amongst the provincial, rural towns of the center. Events forced Gobetti to refocus his militant idealism onto the renewal of liberalism as a radical, emancipatory outlook responsive to concrete social and political struggles. Thus for Spriano, 1920 represents "the great turning point for Gobetti," seeing both his absorption into the factory council debates in Turin and, eventually, the arrival of his new publication, La Rivoluzione Liberale. $^{31}$

\section{LIBERAL REVOLUTION}

Gobetti followed other young radicals in his immense esteem for the Russian revolution of 1917. His initial steps towards rethinking his liberal outlook had already been made in his interpretation of the revolution which he viewed as a positive act of liberation from authoritarianism. In May 1919 he surveyed recent literature on Russia and, though acknowledging the defects of socialism as an economic and administrative model, he made a startling claim of Lenin and Trotsky's accomplishment: "Basically, it is the negation of socialism and an affirmation and exaltation of liberalism." ${ }^{32}$ A liberal state, he continued, "is neither the bourgeois state nor the proletarian state"; indeed, the new state in Russia was for Gobetti not an administrative structure at all so much as a "formation of political consciousness": "Tsarism and the Tsarist mentality are dead. Russia is elevating itself to the level of civilization of the western peoples." ${ }^{33}$ This, admittedly partial, analysis of the Bolsheviks' success echoed similar idealist readings in Turin at the time, not least that of the young editor of the new socialist review L'Ordine Nuovo, Antonio Gramsci, another exstudent of the University of Turin whose intellectual formation Gobetti closely paralleled. ${ }^{34}$ Gobetti's contact with the editors of the review (who were initially rather dismissive of the young liberal) ${ }^{35}$ accelerated his understanding of liberalism as a pan-ideological, revolutionary ethos.

Gobetti had earlier been adamant that revolutionary action was unnecessary in developed countries like Germany and Italy. ${ }^{36}$ However, his association with Gramsci was decisive in 
altering his outlook. ${ }^{37}$ It brought him into contact with Turin's industrial proletariat and a concrete example of a non-party politics that aspired to build a new form of state within the decline of the old. During the so-called biennio rosso of 1919-1920, the industrial plant workers of Turin and elsewhere intensified their conflicts with management over wages and the post-war role of grievance committees. The L'Ordine Nuovo group, or ordinovisti, exalted the modernity of the factory system and Gramsci, in particular, set out a vision of the Turin conflicts as a preparation for the emergence of a whole new civilization built upon an organic society of producers. ${ }^{38}$ In September 1920 the dispute intensified and, in anticipation of being locked out, the workers occupied the factories. Staying there almost a month, they continued to work independently of management. The ordinovisti provided a revolutionary theoretical rationale to the movement, outlining a society of factory councils to replace the defunct parliamentary democracy.

This new model of intellectual and political engagement fascinated the nineteen year-old Gobetti and hastened his disillusionment with Salveminian reformism. Although deeply critical of parliamentary socialism for its collusion with the liberal regime, his enthusiasm for the factory workers was clear when, on 7 September 1920, he wrote to his fiancé, Ada Prospero:

Here we are in the full flow of revolution. I am following with sympathy the efforts of the workers who really are constructing a new order. I don't feel the urge to follow them in their work, at least just now. But, little by little, it seems to me that the greatest battle of the century is being clarified and imposed. Then my place will be with those who have most religiosity and spirit of sacrifice. Today the revolution is posed in all its religious character. Certainly, the hour is difficult even for the workers. By now, at least in Turin, they have liquidated the organizers and the old abstractionist and corrupt leaders, and they are doing things themselves. ${ }^{39}$

Although he remained at some distance from the factory struggles themselves, the experience convinced him that the workers' revolutionary struggle was the central thrust in bringing about, from below, the revitalization of culture and politics to which he aspired. Despite the occupations' ultimate failure to initiate the revolutionary upsurge for which 
L'Ordine Nuovo had hoped (the workers eventually returned to the factories after the unions organized a compromise), Gobetti's political loyalties had been dramatically changed. The future, he was convinced, lay with the workers and their assertion of autonomy from the illiberal, protectionist state. ${ }^{40}$ In January 1921 he took up the post of drama critic for L'Ordine Nuovo at Gramsci's invitation when the paper became a daily. In February the following year, after a number of months of compulsory military service, he began publishing his new journal, La Rivoluzione Liberale (“Liberal Revolution”). There he set about publicizing a new, revitalized liberal outlook and developed a reputation as a powerful political critic, just as Italy swung to anti-socialist reaction and Mussolini's fascists prepared their ascendancy.

The central elements of Gobetti's "revolutionary liberal" project were set out in the opening pages of the first issue of the review. There he proposed to set about forming a new political class with a "clear awareness of its historical traditions and the social needs born from the participation of the people in the life of the state." ${ }^{41}$ Producing a new ruling class was to be achieved by critically confronting Italy's historical failings as a liberal state and seeking their resolution in the postwar conditions of political struggle.

In the central article of that first issue, "Manifesto," Gobetti laid out the historical perspective orienting the project. Italy's current political dilemmas consisted, fundamentally, in its inability to constitute itself as a "unitary organism"; this itself derived from the incapacity of its citizens to form an "awareness of the state." For Gobetti, the lack of a ruling class, of a modern economy, and hence the experience of exercising liberty, further contributed to these failings.

Deprived of liberty, we were deprived of an open political struggle. The first principle of political education was absent, namely the choice between ruling classes. While the vitality of the state, presupposing -in whatever form - the adhesion of citizens, is based precisely on the ability of each to act freely and to realize this way the necessary work of participation, control, opposition. ${ }^{42}$

Whilst various intellectual and political efforts in the nineteenth century had been made to develop a sense of liberty as the basis of political community, the Italian state was eventually formed not through the projection of a common culture but through shifting alliances between 
sectoral interests that eventually "corroded" the relation between government and people: the post-Risorgimento state emerged as "a government without validity and without autonomy because abstracted from the real conditions and founded on compromise; a people educated in materialism, without conscience and will, in a perennially anarchic attitude before any social organization." 43

In the post-war environment, however, old liberalism was "dead," killed by Giolitti, Catholicism and parliamentary democratic socialism, none of whom managed to answer the question of how to make a national political community. Nevertheless, Gobetti saw in the unfolding political crisis and popular struggles a timely resurgence of the aspiration to exercise liberty. It was the self-appointed task of his review "to adhere to all the experiences of autonomy by proposing to clarify, help, and renew ... this movement of popular redemption." ${ }^{44}$ Privileged amongst these demands for autonomy was the workers' movement which "has been in these years the first lay movement in Italy, the only one capable of bringing to its logic the modern, revolutionary value of the state, and of expressing its antiCatholic, religious ideality, denying all Churches." 45

Gobetti's sympathies for the Turin communists were, however, subordinate to a wider vision of liberalism as an ethic of liberation grounded in the spontaneous movement of history. ${ }^{46}$ Here he drew upon the liberalism of Luigi Einaudi, economist and commentator whose classes Gobetti attended at university. For Einaudi-a free-market liberal deeply opposed to state protectionism-the open clash of class interests was the spur to social progress. Left to its own devices - that is, watched from afar by a non-interfering and minimal state-civil society ought to be left free to produce its own compromises. Gobetti shared neither Einaudi's individualism nor his rigid anti-statism, ${ }^{47}$ but he fully endorsed the idea of an intrasocietal struggle for group autonomy as the premise of a liberal ethic. ${ }^{48}$ Not unlike Gramsci's socialism, Gobetti's reading of liberalism was filtered through the work of Georges Sorel, in particular his idea of "myth" as a form of collective consciousness derived spontaneously from the experience of struggle. The workers' movement, Gobetti argued in a letter of August 
1920, was "the only valid force in political life, because it is the only one that can act, in a sorellian way, as myth." ${ }^{49}$ Where Gramsci identified myth with socialism, however, Gobetti saw it as essentially liberal. Thus his praise for the Turinese proletariat's recognition of the "revolutionary value of the state" continued to understand the term "state" not as a concrete apparatus of power (as, in this instance, it was for Gramsci) but as an organized collective consciousness. It was precisely this galvanizing, disciplining force of a revolutionary consciousness á la Sorel that attracted Gobetti, not its immediate aims as such. If socialism was the "starting point" for this myth, "the point of arrival is always liberalism, history; the painful contingency of problems and solutions that are never in a preconceived system because they are born from the practical conciliation of that system and all the others according to which men think." ${ }^{\text {"0 }}$

Gobetti's association with Gramsci and L'Ordine Nuovo led some to consider him of the same ideological camp, an accusation he angrily rebuked: "I am diametrically opposed to Gramsci. My ideas are the fruit of a mature and in-depth examination of the failure of the Italian revolution of the 1800s." ${ }^{51}$ This comment disguises Gobetti's admiration for Gramsci, displayed clearly elsewhere,$^{52}$ but it points to his comprehensive philosophical rejection of reformist socialism, communism and Marxism as political doctrines. ${ }^{53}$ Only in so far as these converged on liberalism's emancipatory principles were they of interest to him. Gobetti conceived the workers' movement as an agent for liberalism's revolutionary values, not an ideal model of economy and politics.

Gobetti's view that liberalism referred essentially to the struggle for liberty rather than to the exercise of specific liberties provided a theoretical platform intended to enable liberals to identify with radical programmes which were not themselves explicitly liberal. In this view, the concept of liberty was understood in a "political" sense, that is, it was associated with demands for collective autonomy and not exclusively with a "negative" concept of individual liberty, to use Isaiah Berlin's categories, in which liberty involves an individual's ability to act without hindrance. Equally, however, Gobetti was not supplanting the negative concept with 
a "positive" or "thick" view of human ends as such, bar the implicit view that liberty, sharpened through conflict, would serve to realize human potential. His instincts remained broadly with the classical defense of individual liberty. As Meaglia argues, on both economic and cultural questions Gobetti typically defended the free initiatives of individuals to act without the paternalistic interference of the state or any other agency. ${ }^{54}$ In this sense he remained an "economic" liberal.

But Gobetti was aware that the political environment within which negative liberties were to be defended was, certainly in Italy, still incomplete. It was to this, fundamentally political, objective that his revolutionary liberalism was primarily directed. In some respects, Gobetti's views resemble the work of recent proponents of classical republicanism like Quentin Skinner for whom negative and positive conceptions of liberty need not be opposed. Rather, negative or individual liberty is conceived as being inseparable from a shared political liberty, that is, the freedom of the community as whole from unwarranted or arbitrary interference in its collective decision-making. ${ }^{55}$ Although not elaborated analytically this way, Gobetti's agonistic liberalism suggested a similar overlapping of individual and political liberty, but focused particularly on the political side in which struggles for collective autonomy emerged. This political liberalism, promoted as a cultural, "religious" or "ethical" outlook, enabled Gobetti to speak across ideological divisions and identify with evidently non-liberal movements such as council communism. ${ }^{56}$

Getting people to think, to undergo a political education adequate to the historical circumstances, then, was the practical thrust of Gobetti's revolutionary liberalism and the goal to which his new review was directed. As he put it himself: "Our task today is not to elaborate a program of government ... but to elaborate a program of action within the state, to create a unity and not to presuppose it." ${ }^{57}$ Political education, of course, needed its teachers and Gobetti's program was openly directed at forging a new "aristocracy," an elite to channel demands for autonomy into a coherent worldview. Here, Gobetti reflected the widespread influence of the Italian political scientist and theorist of the "ruling class," 
Gaetano Mosca, who then also taught at the university. Mosca's claim that political life was characterized by a struggle between elites over the offices of power was adapted by Gobetti to underscore the clash of ideals amongst social forces as they define themselves against prevailing forms of power: "The world is made by small minorities: these can and must be educated-rationally." ${ }^{58}$ New social groups and classes produce new elites who struggle for domination and develop new myths to sustain them. Gobetti's view of elites lacked Mosca's conservatism and cynicism towards popular movements in that it viewed the clash of social forces as a positive source for the renewal of liberty and understood elites as more or less genuine representatives_rather than detached manipulators-of the groups from which they emerged. ${ }^{59}$ When talking of the Turin factory council movement, Gobetti typically underlined his interest not in the mass of workers but in the "heroic minority" of its leaders developing the vision of a new social and political order. Interested neither in their socialism nor collectivism, the workers struggles were significant to him because their praxis "deny all formulae" and their experiences "will end by bringing us a new ruling class." ${ }^{60}$ The crucial aspect of the struggles was, evidently, less the participation of ordinary workers than the moral guidance offered by its leaders. ${ }^{61}$

After the defeat of the factory council movement in September 1920 and the subsequent formation of the Communist Party in 1921 (which absorbed, and effectively neutralized, Gramsci and the ordinovisti), Gobetti realized that the formation of a new elite would be some time in coming. Whilst resolutely convinced the workers would be at the head of any revolutionary movement, his attention shifted back to the legacy of the Risorgimento and the currents of radical thought within Italian political culture past and present. ${ }^{62}$ Rivoluzione Liberale was directed precisely towards those liberal intellectuals and educated middle classes desirous of change but who, thought Gobetti, would not ally with the workers for fear of abandoning liberal principles. Revolutionary liberalism was itself a method of analysis designed to expose the connection between those principles and the social conflicts then underway. ${ }^{63}$ The real test of liberal values, he was proposing, was not in the comfortable distance of abstract ideals but in the gritty terrain of historical reality. 


\section{FASCISM: THE AUTOBIOGRAPHY OF A NATION}

By then, however, historical reality was turning against liberal values with a vengeance. Mussolini's fascists fanned the flames of anti-socialist reaction with effect when, in late 1920, self-organized bands of militia, or squadri, began undertaking "punishment expeditions" against socialists and unions in the countryside and provincial towns. A violent response to the gains made by the left in the previous two years, squadrismo succeeded in part because of the tacit support of the authorities (and a good part of the liberal elite) and dramatically expanded Mussolini's bases of support amongst agrarian landowners and rural conservatives. The fascists formally organized as a party in 1921 amidst a widespread breakdown in public order that Mussolini masterfully exploited to his advantage by presenting himself as the broker of public order. In October 1922, in the absence of stable parliamentary consensus for the liberals, Mussolini was invited to be prime minister, heading a coalition of liberals and fascists. ${ }^{64}$ In this initial period of fascism's rule, most liberal politicians and commentators believed Mussolini's popularity could be exploited to restore social order and public support for parliamentary politics. Even moderate liberals like Croce, though offended by the fascists' populist nationalism, initially sought out "something good" in its parliamentary coalition. ${ }^{65}$ Gobetti, however, grasped very early on its fundamentally anti-liberal orientation and as early as May 1922 he dedicated Rivoluzione Liberale to interpreting the phenomenon and warning other liberals of the threat it posed. ${ }^{66}$

Gobetti's initial response to fascism was politically dismissive yet theoretically incisive. He shared a common revulsion amongst educated liberals at the crude, rhetorical posturing of Mussolini and his movement's violent, anti-socialist tactics. The fascists, he claimed, were a contradictory and unstable collection of bellicose urban petty-bourgeoisie and agrarian reactionaries, "palingenetics" trading on the myth of revolution but whose internal disagreements and class divisions couldn't be hidden. ${ }^{67}$ As for Mussolini, he was an opportunist and a dogmatist, an anachronistic condottiere leading a band of savages. He lacked the creativity and the religious character of a proper leader. ${ }^{68}$ 
In addition to these comments, however, Gobetti developed a more sophisticated view. Fascism represented more than a temporary and distasteful disruption of political life; it symbolized Italy's historical failings as a nation-state. ${ }^{69}$ For all its revolutionary rhetoric, fascism implied a continuation of the traditional practices in Italy of substituting open conflict with consensus, compromise and collaboration between political leaders; thus, "Fascism is the legitimate heir of Italian democracy."70 In "Elogio della Ghigliottina," written just after Mussolini's so-called "seizure" of power, Gobetti memorably defined fascism as the "autobiography of a nation": in it was condensed all of Italy's cultural and political failings, principally an immaturity of Italians and their party political representatives preventing them from facing up to the liberating force of social and political conflict. ${ }^{71}$ The "disaster" of fascism lay in its violent and illiberal denial of heresy, but this was a disaster with deep roots in Italy, populated as it was by a people with "the spirit of slaves."

But exactly what kind of political (as opposed to cultural) resistance to fascism Gobetti was offering was unclear. Indeed, at various points in his analysis of the political situation, Gobetti himself seemed curiously aloof. Because he opposed the socialist parliamentary grouping (indeed, he castigated all parliamentary party politics ${ }^{72}$ ), he suggested, there was no point in resisting fascism simply to return to the status quo ante. The country, he argued, needed a test and the arrival of fascism was an opportune moment to see if Italy was prepared to fight for its liberty. Refusing to collaborate with fascism's parliamentary critics ("To fight against Mussolini only in order to replace him in six months with Nitti, Cocco-Ortu, Orlando or Giolitti. No and no again") Gobetti suggested it was necessary to let fascism run its course: "We remain historians over and above the day-to-day ... and we work for another revolution."73 Not for the first time was Gobetti's program open to the accusation of being an ineffectual, cultural rather than directly political action.

However, Gobetti's political instincts were sharpened in June 1924 following the murder of the reformist socialist deputy, Giacamo Matteotti, by fascist heavies in Rome. Matteotti had openly denounced the elections of April that year which were conducted in an atmosphere of 
intimidation and which were organized under a new electoral system designed to reward the largest party with a disproportionately large number of seats. Not surprisingly, the fascists made significant gains and Matteotti's defiance deliberately threatened publicly to discredit Mussolini. ${ }^{74}$ Matteotti's brutal murder, evidently undertaken with the support of the prime minister, generated widespread revulsion among the parliamentary opposition many of whom marched out of the Chamber of Deputies in protest. ${ }^{75}$

The "Aventine secession," as it was called, seemed for a moment to unify the various opposition parties and threatened to withdraw any constitutional recognition for Mussolini who still relied on the support of conservative elites. Gobetti now saw the potential for an intransigent anti-fascist politics led by mass parties; ${ }^{76}$ he narrowed down his disdain to the older constitutional parties alone ${ }^{77}$ talked up the idea of a modern, European democratic parliament, ${ }^{78}$ and recruited "Liberal Revolution Groups" to promote an inclusive coalition. ${ }^{79}$ However, the Aventine's aspirations, such as they were, and particularly those articulated by its leader, the liberal deputy Giovanni Amendola, were strictly legalistic in that they aimed to invoke an intervention by the Monarch to remove Mussolini. ${ }^{80}$ By consequence, and in part because of remaining animosities between the parties, the Aventine failed to act sufficiently quickly or effectively to dislodge Mussolini. ${ }^{81}$ Outside of parliament, they were unable able to mobilize the doubters who remained in the Chamber and Senate and the prime minister survived the immediate storm.

In January 1925, Mussolini dramatically announced his intention to install an authoritarian order. ${ }^{82}$ Measures were taken immediately to curtail freedom of assembly and association, particularly against suspected "subversives" and by October the regime began to suppress opposition parties and arrest their leaders. ${ }^{83}$ Gobetti succeeded that year in publishing a book version of La Rivoluzione Liberale collecting his various articles from the journal in a narrative historical study of political struggles in contemporary Italy. ${ }^{84}$ However, the review itself produced its last number in November after the authorities ordered Gobetti to cease all editorial and publishing activities. Already unwell with heart problems after an assault by 
fascists, he decided to move to Paris in the new year. There he intended to resume his antifascist politics with other radical liberal sympathizers. However, to the shock of his companions back in Turin, he never recovered from his ill-health and towards midnight of 15 February 1926 he died of heart failure. ${ }^{85}$

\section{LIBERTY AND STRUGGLE}

Twenty-first century liberal democracies are by now long accustomed to the cut and thrust of party competition and the polemical character of public debate. Such conflict is largely assumed to sit safely behind the walls of a broad consensus on the value of individual liberty and its institutions. Once those walls are breeched, however, liberals have frequently proved themselves a remarkably illiberal bunch, prone to invoke the authority and force of the state they otherwise resent. Such indeed was the inclination of many liberals, such as Croce, in Italy after the First World War. Gobetti, then, offers a salutary reminder of what can happen if we rely excessively on the language of consensus and pay too little attention to the conflictual conditions from which consensus arises. To properly grasp this message, we need to return to the conceptual linkage he made between liberty, conflict and struggle. ${ }^{86}$

As Bagnoli indicates, Gobetti's liberalism was not a doctrine of the state that sketched its proper functions and relations to the individual citizen. Rather, it was an outlook on history and society focused on the continuous, conflictual formation of new demands for liberty and autonomy. ${ }^{87}$ Following Croce, Gobetti rejected efforts to ground liberalism in a transcendental philosophical framework. Liberty was not an abstract concept but a dialectical impulse in history itself. Thus it could take any number of forms and express itself through a variety of societal agents, not only the bourgeoisie. Liberal values did not emerge exclusively with any specific class but from the clash of forces in society which constantly throws up new demands for liberty—or better, liberation—from conditions of tyranny and oppression. Only in the struggle to resist economic, cultural and political heteronomy did freedom find its most adequate expression and most challenging test. Without these conditions of struggle and conflict, liberty simply grew stale and conservative. Thus the Italian state had crystallized the 
clash of forces but in so doing it prevented any renewal of liberty. ${ }^{88}$ In common with fascism, he claimed, Italian liberals had developed a "fear of politics." 89

It is just this liberal "fear of politics" that around the same time inspired the German legal philosopher and conservative, Carl Schmitt, to formulate his own agonistic outlook. ${ }^{90} \mathrm{~A}$ very brief comparison with Gobetti is illuminating. For Schmitt, too, liberal parliamentarism had denigrated politics in its tendency to foreground compromise and procedure. ${ }^{91}$ In $\underline{\text { The }}$ Concept of the Political he also tried to reassert the "ever-present possibility of conflict" by specifying the distinction between "Friend" and "Enemy" as the essential criterion of "the political." ${ }^{92}$ Yet, Schmitt's line of argument led him to reject liberalism altogether and, eventually, support Nazism. The conflictual basis of politics was, for him, indicative of the need for the state as a sovereign entity to act as supreme arbiter. ${ }^{93}$ Moreover, his concept of the political was indifferent to the content of the conflict that invoked it. ${ }^{94}$ Gobetti, by contrast, focused on politics outside the state and formal politics, adopting the kind of "pluralistic" outlook that Schmitt expressly disliked. Conflict was specified precisely in terms of struggles for liberty, not political enmity in general. Unlike Schmitt, then, for whom domestic politics had to be suppressed if politics was to be affirmed, Gobetti adopted a more democratic agonism in which the state appeared as a potential obstacle to further conflict and not its supreme expression. Thus Schmitt's agonist outlook underscored his later commitment to fascism; whilst Gobetti's propelled him forcefully, and fatally, against it.

Gobetti's message later resounded powerfully in Italy both as a symbol of anti-fascist defiance and, more recently, as a moral critique of the postwar democratic republic. ${ }^{95}$ However, significant tensions remain in Gobetti's thought that his devotees often overlook. Not surprisingly, what is regarded as his great innovation-an ethical liberalism based on the principle of conflict-is also the source of some unresolved difficulties. If liberty has an agonistic basis, then the question arises as to how liberalism can have durability and establish itself as a shared ethic, regulating conflict within its own terms rather than succumbing to endless disputation and violence. 
Gobetti's answer, such as it was, was to invoke the role of elites in clarifying liberal values and leading the wider populace into a new civil philosophy, a recurrent theme in Italian political thought. ${ }^{96}$ As we have seen, this was the explicit purpose of his review, La Rivoluzione Liberale, and a similar objective is detectable in his other publications which focus on the principal role of historical thinkers in advancing liberty as the basis of a new civic religion. ${ }^{97}$ Gobetti invested a great deal in the capacity of emergent elites to grasp the spontaneous movement of freedom and give it "religious" expression in the manner of Sorel's idea of "myth." ${ }^{98}$ But the content of any ideological doctrine was not of primary significance, for its liberal value inhered in its liberatory function, not its explicit goals. New social elites would mobilize the masses towards an expression of freedom, their liberal character deriving from their quest for autonomy and not explicitly from the demands they articulated. Yet the specific goals of any social movement-for instance, the Turinese communists' demands for a self-regulating society of producers-would almost certainly be opposed to change for its own sake, instead preferring to establish a social order on the basis of values and forms of organization considered, if not utterly permanent, at very least appropriate to the specific historical conjuncture. Gobetti provided little justification, then, for thinking that social movements would or should themselves take up liberal values and build institutions that support and sustain these values.

Gobetti believed elites would arise spontaneously amongst social forces, more or less adequately "representing" them through the propagation of myths. ${ }^{99}$ However, his own comments suggest a certain disdain for the wider public and a suspicion that they remain largely incapable of an intelligent understanding of political life: "The masses are only capable of working in short enthusiastic bursts and do not follow a constant directive ...Today they admire and love you: tomorrow they will want to kill you because you remind them of their inferiority." 100 Thus Gobetti's call for "popular redemption" can be read as a moral critique of Italians' capacity for self-enslavement. From this perspective, the "democratic" character of elites resides in their ability to represent the "better" side of Italians and not in any specific mechanism of accountability; this implies an asymmetrical political 
division oriented to producing an enlightened ruling class who can clarify the antagonistic terrain from which they originally emerge. ${ }^{101}$ Meaglia is consequently led to argue that, properly synthesized, Gobetti's liberalism implies a defense of parliamentary democratic institutions based on competition between elites. ${ }^{102}$ His aim, claims Meaglia, was not to substitute the liberal state but to renew it through the formation of a new ruling class "from below." Conflict and struggle, we might continue, would produce this ruling class but it would not prevent it from developing its own consensus of liberal values to "regulate," as Meaglia claims, struggle within the context of parliamentary institutions. ${ }^{103}$

Meaglia's interpretation of Gobetti extrapolates from him a view akin to Schumpeter's 'democratic elitism'. ${ }^{104}$ This assessment is perhaps overstated-as we have seen, Gobetti's enthusiasm for parliamentarism only emerged in earnest after Matteotti's murder ${ }^{105}$-yet it points to a tension in his liberalism between the creative and ever-renewing sense of libertyas-struggle and the need to contain that struggle within parameters that ensure its beneficial (i.e. pro-liberal) results. This is inevitable once liberty is based on the indeterminacy of historical struggles rather than a transcendental epistemology. For it remains a matter of contingent judgement as to how any specific conflict contributes to or detracts from a liberal "religiosity." Agonistic liberalism reminds us that liberty is grounded in conflicts but, by definition, it can tell us neither how to resolve those conflicts nor how to draw from them some sense of "collective renewal." Such things have to be worked out pragmatically. For liberals this situation implies an uncommon burden of political responsibility, a duty both to allow conflicts to occur and to cultivate them into a sense of public "faith". It is no surprise, perhaps, that many liberals have opted instead for the authoritarian response.

The problem of this burden is implied by David Roberts who argues Gobetti's understanding of the role of liberal intellectuals like himself was profoundly ambivalent. On the one hand he identified a role for critically-aware liberal thinkers to advise and nurture new social elites; whilst, on the other, he implied a more modest role of developing a historical understanding of events without actively participating in them. For the most part, claims Roberts, Gobetti 
looked to political struggles rather than to isolated intellectuals to foster a religion of liberty. But in practice, he continues, Gobetti "remained a typical middle-class intellectual divorced from the masses" and his review exuded a "snobbish tone ... seeking to improve Italian political culture." ${ }^{06}$ This "left edge of liberalism," as Roberts calls it, was consequently extremely fragile, attracting young middle-class intellectuals towards new radical movements but not securing these intellectuals in a distinctively liberal program.

Gobetti's liberalism answered the desire to expand liberal values across a divided nation by presenting them as immanent to an unfolding, conflictual reality. In so doing, he followed other Italian intellectuals in extolling the virtues of a civic religion of liberty, a common cultural framework to redeem the nation and inscribe its politics within robust moral ideals. However, like many other liberals he remained uncertain of the role the wider populace might play in this culture and, consequently, ascribed a primary role to elites in imposing intellectual order on the antagonisms of the masses. The tensions in his thought to which this gives risebetween masses and elites, social struggles and intellectual coherence, specific demands for autonomy and broader liberal ideals_-can be understood to stem from this peculiar agonistic construction of a liberal civil religion. They affirm Emilio Gentile's point that the rather distant, high-brow approach to civil religion produced by liberal intellectuals prior to fascism kept them apart from the wider populace and singularly failed to grip the nation in the way they had hoped. ${ }^{107}$

\section{CONCLUSION}

No liberal these days would express sympathies with fascist dictators. But it is less certain, in the face of so-called "security threats" and "clashes" of civilizational cultures, that liberals are genuinely open to the discomforts of deep conflict over the meaning and practice of liberty. In what are often treated as "exceptional" cases, it is all too easy to run to the bunker, let the state do its work and reappear après la lutte clutching the "rules of the game". Gobetti's brief intellectual and political career remind us that the political game-be it an elite-driven democracy or something more "deliberative"-is open to critique, contest and, sometimes 
radical, revision. Unless liberals integrate the concept of liberty into a constitutive dimension of politics, they are at risk of enclosing themselves within a legalistic culture that prioritises consensus over conflict, losing touch altogether with the intellectual and material vibrancy of social polemic. But Gobetti's example also indicates how difficult this lesson is to learn. Inspiring a renewed faith in liberty requires an enormous, perhaps unrealistic, commitment to politics, and an improbable reliance on the virtues of elites to satisfactorily mediate conflict in a way that enriches our understanding of liberty rather than neutralises it.

\section{AUTHOR'S NOTE}

I am grateful to Franca Ranghini and the staff of the "Centro Studi Piero Gobetti" in Turin and to David Bidusa and staff at the Bibliotecha Feltrinelli in Milan for their assistance in accessing materials during the preparation of this essay. I would also like to express my thanks to Professor Massimo L. Salvadori for his helpful advice. Acknowledgement is due, too, to the University of London's Central Research Fund for providing vital financial assistance to enable my research.

\section{REFERENCES}

${ }^{1}$ John Stuart Mill, On Liberty and other writings, ed. Stefan Collini (Cambridge: Cambridge University Press, 1989), 34-5.

${ }^{2}$ Examples of contemporary political philosophers drawing upon agonistic principles include: John Gray, Two Faces of Liberalism (Cambridge: Polity, 2000); Chantal Mouffe, The Democratic Paradox (London: Verso, 2000), and The Return of the Political (London: Verso, 1993); Jacques Rancière, Disagreement: politics and philosophy (Minneapolis: University of Minnesota Press, 1999).

${ }^{3}$ John Gray, Enlightenment's Wake: politics and culture at the close of the modern age (London: Routledge, 1995), 68.

${ }^{4}$ See the excellent introduction by Nadia Urbinati to the English translation of selections from Gobetti's writings: "Introduction: Liberalism as a Theory of Conflict," in On Liberal Revolution, ed. Nadia Urbinati (New Haven \& London: Yale University Press, 2000). 
${ }^{5}$ Stanislao Pugliese, ed., Italian Fascism and Anti-Fascism: A Critical Anthology (Manchester and New York: Manchester University Press, 2001), 61-2.

${ }^{6}$ The idea of civic religion in Italian political discourse is discussed in Emilio Gentile, The Sacralization of Politics in Fascist Italy (Cambridge, Mass. and London: Harvard University Press, 1996), 1-18.

${ }^{7}$ For an overview of the decline of the liberal regime, see Paul Corner, "State and society, 19011922," in Liberal and Fascist Italy, ed. Adrian Lyttelton (Oxford: Oxford University Press, 2002).

${ }^{8}$ On the civic role of Turin's university, as well as Gobetti's relation with it, see Angelo d'Orsi, La cultura a Torino tra le due guerre (Turin: Einaudi, 2000).

${ }^{9}$ Efforts by the liberal elite to stem the tide of revolt are discussed in Martin Clark, Modern Italy, 18711995, second ed. (London and New York: Longman, 1996), 203-13.

${ }^{10}$ See Norberto Bobbio, Trent'anni di storia della cultura a Torino (1920-1950) (Turin: Einaudi, 2002), 40-3.

${ }^{11}$ See Benedetto Croce, Cultura e vita morale (Bari: Laterza, 1914).

${ }^{12}$ On Croce's historicism and its impact, see Edmund E. Jacobitti, Revolutionary Humanism and Historicism in Modern Italy (New Haven and London: Yale University Press, 1981) and David D. Roberts, Benedetto Croce and the Uses of Historicism (Berkeley: University of California Press, 1987); and Richard Bellamy, "Liberalism and Historicism: Benedetto Croce and the political role of Idealism in Italy c. 1880-1950," in The Promise of History, ed. A. Moulakis (Berlin/New York: Walter de Gruyter, 1985).

${ }^{13}$ In his first letter (of 27 November 1918) to Croce he claimed of his review: "the basis of our action would be the same militant idealism that animated ... La Voce," Piero Gobetti, Carteggio 1918-1922, ed. Ersilia Alessandrone Perona (Turin: Einaudi, 2003), 5. See also Gobetti's admiring remarks on Croce to Santino Caramela (17 December 1918): "I have a very great admiration for Croce who I believe without doubt is the man who has worked more than any other for the good of our culture, and also I believe him to be the most genial and most Italian philosopher after Vico," Gobetti, Carteggio, 12. See also Gobetti's various public defenses of Croce: "B. Croce e i pagliacci della cultura," Energie Nove (15-30 November 1918), in Scritti politici, ed. Paolo Spriano (Turin: Einaudi, 1960) (hereafter SP) and "Croce oppositore," La Rivoluzione Liberale (6 September 1925), SP, 17-21; "Nota III [I crociani]," Energie Nove (1-15 January 1919), SP, 46.

${ }^{14}$ See also Gobetti, "Giolitti, giolittismo e antigiolittismo," Energie Nove (5 July 1919), SP, 125-8.

${ }^{15}$ Gobetti, "La Nostra Fede," Energie Nove (5 May 1919), SP, 77.

${ }^{16}$ Ibid., 78. 
17 Ibid., 86-7.

18 Ibid., 88.

19 Ibid., 87.

${ }^{20}$ For a profile of Salvemini, see Norberto Bobbio, Ideological Profile of Twentieth-Century Italy, trans. Lydia G. Cochrane (Princeton, NJ: Princeton University Press, 1995), 86-90.

${ }^{21}$ In addition to a number of articles by Gobetti, as well as others, scattered throughout the reviewsee, Gobetti, "Il problema della scuola media [I] II liceo," Energie Nove (1-15 March 1919), SP, 53-65; "Il problema della scuola media [II] II ginnasio," Energie Nove (15-31 March 1919), SP, 66-70._ Energie Nove also devoted a special issue (Series II, no. 9) to scholastic reform.

22 Gobetti, "Traditore o incapace?," Energie Nove (1-15 December 1918), SP, 28-9. In 1919 Gobetti headed the Turin section of the "Friends of L'Unitá [Salvemini's newspaper] Action Groups" established to promote a number of related causes such as electoral reform, votes for women, and Italy's membership of Woodrow Wilson's “League of Nations." In April of that same year, he and other supporters of L'Unitá attended a congress in Florence, renaming the group "The Democratic League for the Renewal of National Politics." There Gobetti even received an invitation from Salvemini to take over the editorship of L'Unitá; an offer, nevertheless, that he declined.

${ }^{23}$ Clark, Modern Italy, 204-5.

${ }^{24}$ Ibid., 212-13.

${ }^{25}$ See Gobetti, "Frammenti di estetismo politico," Energie Nove (30 November 1919), SP, 164-78.

${ }^{26}$ See his letters to Santino Caramella and to Giovanni Ansaldo of July, August and October 1919:

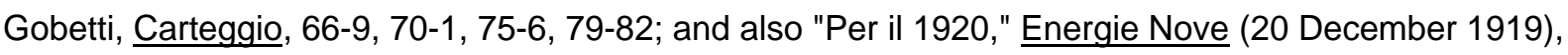
$\underline{\mathrm{SP}}, 178-80$.

27 See Gobetti, "Intermezzo," Energie Nove (12 February 1920), SP, 181-2.

28 See his letter to Caramella of 18 February 1920: Gobetti, Carteggio, 98-103.

${ }^{29}$ See his letter to Caramella of 13 February 1920, Ibid., 95-6. Throughout 1920 Gobetti continued to suggest in correspondence that he intended to republish Energie Nove.

${ }^{30}$ See Gobetti, "Esperienze liberale [VI]," La Rivoluzione Liberale (18 June 1922), SP, 378-80.

${ }^{31}$ See Paolo Spriano, Gramsci e Gobetti, third ed. (Turin: Einaudi, 1977), 106. 
32 Gobetti, "Rassegna di questioni politiche," Energie Nove (25 July 1919), SP, 151; see also his remarks on Trotsky: "Trotzki," ㅆ Resto del Carlino (5 April 1921), SP, 206-10.

${ }^{33}$ Gobetti, "Rassegna di questioni politiche," 152, 51, 52.

34 On Gobetti's response to the Russian revolution, see Bruno Bongiovanni, "Piero Gobetti e la Russia," Studi storici 37, no. 3 (1996). The remarkable intellectual parallels between Gramsci and Gobetti are explored in Spriano, Gramsci e Gobetti.

35 The editors of L'Ordine Nuovo had originally been dismissive of Gobetti and Energie Nove. In a scathing critique of the young liberal's exuberant language and imagery, Palmiro Togliatti attacked Gobetti for using "a system of semi-obscure expressions, words that are meant to be profound and mysterious. What is this bad habit of not being able to say four clear phrases ... without disturbing all the gods and idols of the idealist heaven? What is this raising at any trifle the entire arsenal of the Spirit, the Absolute and the Ideal and so on?," Palmiro Togliatti, "Parassiti della cultura," L'Ordine Nuovo (15 May 1919). Gobetti mentioned the attack in a letter to Caramella (see Gobetti, Carteggio, 54) but publicly dismissed it in his review. See Gobetti, "Polemica con L'"Ordine Nuovo" (Nota)," Energie Nove (15 May 1919), SP, 113-15.

${ }^{36}$ See, for example, Gobetti, "La rivoluzione italiana. Discorso ai collaboratori di "Energie Nove","

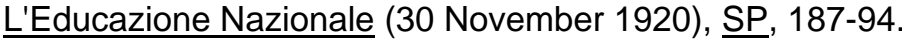

${ }^{37}$ d'Orsi, La cultura a Torino, 53.

${ }^{38}$ On Gramsci and the ordinovisti's involvement in the factory council struggles, see Martin N. Clark, Antonio Gramsci and the Revolution that Failed (New Haven and London: Yale University Press, 1977); Darrow Schecter, Gramsci and the theory of industrial democracy (Aldershot: Avebury, 1991); and Paolo Spriano, L'occupazione delle fabbriche, settembre 1920 (Turin: Einaudi, 1964).

39 Piero Gobetti and Ada Gobetti, Nella tua breve esistenza. Lettere 1918-1926, ed. Ersilia Alessandrone Perona (Turin: Einaudi, 1991), 375-6.

${ }^{40}$ Gobetti wrote a supportive retrospective study of the Turin communists and their role in the factory council movement, "Storia dei comunisti torinesi scritta da un liberale," La Rivoluzione Liberale (26 March 1922), SP, 278-95.

${ }^{41}$ Gobetti, "Ai lettori," La Rivoluzione Liberale (12 February 1922), SP, 225-6.

42 Gobetti, "Manifesto," La Rivoluzione Liberale (12 February 1922), SP, 229.

43 Ibid., 236. In a later article reflecting on the debate generated by 'Manifesto', Gobetti reasserted the need for this critical, historical view of liberalism's success. See Gobetti, "Politica e storia (Polemica

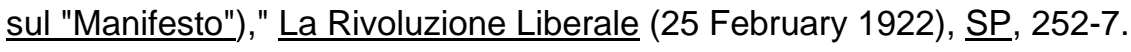


${ }^{44}$ Gobetti, "Manifesto," 237.

45 Ibid., 239.

${ }^{46}$ On this view of liberalism, see Gobetti, "Liberali e conservatori," La Rivoluzione Liberale (26 March 1922), SP, 277.

47 Gobetti's rejection of atomistic individualism is evident in his comments on the ideas of Guido De Ruggiero in a letter to Ada Prospero of 1921: "De R[uggiero] is now entirely taken by English economic liberalism: he wants an individualistic liberalism, which I would define as atomistic. He doesn't understand the need for a national popular movement for the reconstruction of the state; he deludes himself that this can be attained by a reformist movement. Ultimately his conception no longer understands social struggle and he reduces reality to a mechanical composition of facts, without seeing how the result must always be a synthesis of wills." Gobetti and Gobetti, Nella tua breve esistenza, 449.

48 Gobetti made a public assessment of Einaudi in "Il liberalismo di L. Einaudi," La Rivoluzione Liberale (23 April 1922), SP, 322-36. For a profile of Einaudi, see Bobbio, Ideological Profile, 82-6.

${ }^{49}$ Gobetti, Carteggio, 140. On the influence of Sorel on Gobetti, see Pietro Polito, "Gobetti e Sorel," Mezzosecolo: materiali di ricerca storica 6 (1985/1986).

50 Gobetti, Carteggio, 141.

51 Ibid., 183.

52 Gobetti may have disagreed with the content of Gramsci's communism but he undoubtedly admired its political and historical value. In 1921 Gobetti tried to have Gramsci's factory council writings published. See his letters to Prezzolini, Ibid., 209, 11-12. and also Gobetti's affectionate portrait of Gramsci at 119-26. Gobetti's esteem remained evident years later when Gramsci entered parliament as a communist deputy. See Piero Gobetti, "Uomini e idee [X]," La Rivoluzione Liberale (22 April 1924), SP, 644-47.

53 Gobetti, Carteggio, 194, 205, 22. See also his scathing critique of the socialist leader Fillipo Turati, "Letture sui partiti politici," La Rivoluzione Liberale (8 April 1922), SP, 304-8.

${ }^{54}$ Piero Meaglia, "Gobetti e il liberalismo. Sulle nozioni di libertà e di lotta," Mezzosecolo: materiali di ricerca storica 4 (1980-1982).

55 See, for example, Quentin Skinner, "A Third Concept of Liberty," Proceedings of the British Academy 117 (2002). 
${ }^{56}$ See, for example, Gobetti's distinction between economic liberalism and a liberalism concerned with 'political conscience': "Il liberalism e le masse [I]," La Rivoluzione Liberale (10 April 1923), SP, 477-8.

57 Gobetti, Carteggio, 222.

${ }^{58}$ Gobetti to Ada, 9 September 1921, Nella tua breve esistenza, 500.

59 See Gobetti, "La rivoluzione italiana. Discorso ai collaboratori di 'Energie Nove'" where he talks of an "elitism open to all." For Gobetti's assessment of Mosca, see "Un conservatore galantuomo," La

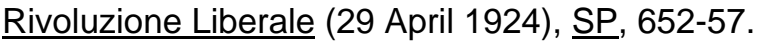

${ }^{60}$ Gobetti, Carteggio, 160.

61 Thus Gobetti claimed it was not necessary that workers themselves consciously take up a liberal view of history for their struggles to be categorized as liberal. See "Esperienza liberale," La

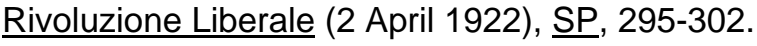

62 Paolo Bagnoli, Piero Gobetti: cultura e politica in un liberale del Novecento (Florence: Passigli, 1984), 71.

63 Ibid., 72-4. See also "I presupposti economici del liberalismo (Postilla)," La Rivoluzione Liberale (19 February 1922), $\underline{\text { SP, }}$ 249-50.

${ }^{64}$ On the rapid rise of fascism between 1920 and 1922, see R. J. B. Bosworth, Mussolini (London: Arnold, 2002); Clark, Modern Italy, 213-24.

65 See Fabio Fernando Rizi, Benedetto Croce and Italian Fascism (Toronto: University of Toronto Press, 2003), 43-9.

${ }^{66}$ Bagnoli, Piero Gobetti, 76.

67 Gobetti, "Esperienza liberale [V]," La Rivoluzione Liberale (28 May 1922), SP, 354-7; "Note di politica interna [l]," La Rivoluzione Liberale (30 July 1922), $\underline{\text { SP }}$, 397-400.

${ }^{68}$ Gobetti, "Uomini e idee [V]," La Rivoluzione Liberale (28 May 1922), SP, 358-61.

${ }^{69}$ On Gobetti's distinctive interpretation of fascism, see Marco Revelli, "Piero Gobetti e il fascismo. La teoria della "rivelazione,"' in Perché Gobetti. Giornata di studio su Piero Gobetti (Torino, 16 aprile 1991), ed. Cesare Pianciola and Pietro Polito (Turin: Piero Lacaita, 1993).

${ }^{70}$ Gobetti, "Noi e le opposizioni," La Rivoluzione Liberale (22 April 1924), SP, 644.

71 Gobetti, "Elogio della ghigliottina," La Rivoluzione Liberale (23 November 1922), SP, 431-4. For his critique of political parties, see "Note di politica interna [I]." Gobetti also accused the Socialist Party of 
being essentially similar to the fascists in seeking a politics of "collaboration" rather than principle. See "Note di politica interna [III] (Risposta a M. A. Levi)," La Rivoluzione Liberale (10 September 1922), SP, 406.

${ }^{72}$ See, for example, his comprehensive diagnosis of Italian political culture: Gobetti, "La nostra cultura politica," La Rivoluzione Liberale (8 March 1923), SP, 456-76.

${ }^{73}$ Gobetti, "Questioni di tattica," La Rivoluzione Liberale (23 November 1922), SP, 429-30.

${ }^{74}$ On Matteotti's murder and its effects, see Adrian Lyttelton, The Seizure of Power. Fascism in Italy, 1919-1929 (London: Weidenfeld and Nicolson, 1973), 237-40.

${ }^{75}$ For Gobetti's response to Matteotti's murder, see "Due tattiche," La Rivoluzione Liberale (24 June 1924), SP, 732-4; "Ho conosciuto Matteotti," La Rivoluzione Liberale (17 June 1924), SP, 707-8; "Matteotti," La Rivoluzione Liberale (1 July 1924), SP, 735-52.

${ }^{76}$ Gobetti, "La settimana," La Rivoluzione Liberale (25 November 1924), SP, 793-800; "La situazione," La Rivoluzione Liberale (8 July 1924), SP, 752-7.

77 See, for example, Gobetti, "Saluto all'altro parlamento," La Rivoluzione Liberale (11 November 1924), $\underline{\text { SP, }}$ 791-3.

${ }^{78}$ See Gobetti, "La successione," La Rivoluzione Liberale (10 December 1924), SP, 801-4.

${ }^{79}$ Gobetti, "Gruppi della "Rivoluzione Liberale,"' La Rivoluzione Liberale (8 July 1924), SP, 758-60.

${ }^{80}$ Lyttelton, The Seizure of Power, 242-3.

${ }^{81}$ Ibid., 258.

${ }^{82}$ See Ibid., 265-7.

${ }^{83}$ Ibid., 267-8.

${ }^{84}$ See Piero Gobetti, La Rivoluzione Liberale, ed. Ersilia Alessandrone Perona (Turin: Einaudi, 1995).

${ }^{85}$ For details on Gobetti's death and tributes paid to him by Einaudi and others, see the special issue

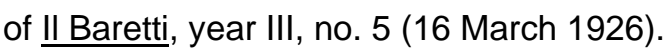

${ }^{86}$ See Meaglia, "Gobetti e il liberalismo," 194-6.

${ }^{87}$ Bagnoli, Piero Gobetti, 93.

${ }^{88}$ Gobetti, "Liberali e conservatori." 
${ }^{89}$ Gobetti, "Democrazia," La Rivoluzione Liberale (13 May 1924), SP, 677.

90 See Carl Schmitt, The Concept of the Political, trans. George Schwab (Chicago and London: University of Chicago Press, 1996).

91 See Carl Schmitt, The Crisis of Parliamentary Democracy, trans. Ellen Kennedy (Cambridge, Massachusetts and London: MIT Press, 1988).

${ }^{92}$ Schmitt, The Concept of the Political, 32.

${ }^{93}$ For a discussion of conflict in Schmitt, see William Rasch, "Conflict as a Vocation: Carl Schmitt and the Possibility of Politics," Theory, Culture \& Society 17, no. 6 (2000).

94 "The political can derive its energy from the most varied human endeavors, from the religious, economic, moral, and other antitheses. It does not describe its own substance, but only the intensity of an association or disassociation of human beings whose motives can be religious, national (in the ethnic or cultural sense), economic, or of another kind and can effect at different times different coalitions and separations." Schmitt, The Concept of the Political, 38.

95 On Gobetti's influence on the resistance movement, see James Martin, "Italian liberal socialism: anti-fascism and the third way," Journal of Political Ideologies 7, no. 3 (2002). On the continuing resonance of Gobetti's ideas in contemporary Italy, see Paolo Flores d'Arcais, "Gobetti, liberale del futuro," in La Rivoluzione Liberale. Saggio sulla lotta politica in Italia, ed. Piero Gobetti (Turin: Einaudi, 1995).

${ }^{96}$ See Joseph Femia, The Machiavellian Legacy. Essays in Italian Political Thought (Basingstoke: Macmillan, 1998).

${ }^{97}$ For example, see his university graduating thesis of 1922, now available as Piero Gobetti, La filosofia politica di Vittorio Alfieri (Ascoli Piceno: Edizioni Sestante, 1995).

${ }^{98}$ Thus Polito claims that, for Gobetti, Sorel's idea of myth served as a meeting point between masses and elites. See Polito, "Gobetti e Sorel," 45.

${ }^{99}$ See Piero Gobetti, "Il liberalismo in Italia," La Rivoluzione Liberale (15 May 1923).

100 Piero Gobetti to Ada, 9 September 1921, Nella tua breve esistenza, 500. See also Polito, "Gobetti e Sorel," 45-6.

${ }^{101}$ Marco Revelli argues that for Gobetti conflict is a political value superior to autonomy. See Marco Revelli, "Gobetti "liberal comunista"?," in I dilemmi del liberalsocialismo, ed. Michelangelo Bovero, Virgilio Mura, and Franco Sbarberi (Rome: La Nuova Italia Scientifica, 1994), 83-4. 
102 Meaglia, "Gobetti e il liberalismo," 214.

103 Ibid.: 219.

104 See Joseph A. Schumpeter, Capitalism, Socialism and Democracy (New York: HarperPerennial, 1975).

105 Thus Gobetti claimed that for a liberal, the democratic state cannot be equated with an electoral system since a state is formed through an aristocracy derived from the dialectic of liberatory struggle in society. See Piero Gobetti, 'Esperienze liberale [IV],' La Rivoluzione Liberale (23 April 1922), SP, 338-42.

106 David D. Roberts, "Frustrated Liberals: De Ruggiero, Gobetti, and the Challenge of Socialism," Canadian Journal of History 17 (1982): 78.

107 See Gentile, The Sacralization of Politics, 13. 